\title{
Students' Creativity and High-Order Thinking Skills in Laboratory Activity of Surface Chemistry
}

\author{
Bertha Yonata, Siti Tjahjani, Dian Novita \\ Chemistry Department, Universitas Negeri Surabaya, Surabaya 60231, Indonesia
}

\begin{abstract}
Students' creativity and High-Order thinking skills involved in the enrollment of surface chemistry course was examined in this study. The laboratory activity worksheet developed in previous research done by Yonata et al (2017) was used to guide student activity. Meanwhile, the students' creativity was assessed through laboratory report. The instruments used to obtain data on students' high-order thinking have been developed also in previous research by Yonata, et al (2017). High-order thinking skill refers to the revised version of Bloom taxonomy with $\mathrm{C} 4$, C5, and C6 level. The high-order thinking test is an essay test in which a phenomenon is presented and the students' performance was determined by the variables (C5), problem formulation (C4), hypothesis (C6), experimental procedure (C6), experimental analysis $(\mathrm{C4})$, and conclusion (C5). The test was taken by individual students before and after the laboratory activities. From the results of the study, it was obtained come data showing that, in the pretest, there were still $61 \%$ of students who mastered high-order thinking skills while, in the posttest, $100 \%$ of the students completed the skills. Meanwhile, the result of the students' creativity shows that every student had different procedure to conduct experiment shown in the posttest.
\end{abstract}

Keywords-creativity, high-order thinking skills, surface chemistry.

\section{INTRODUCTION}

The student's worksheet of laboratory activity produced by Yonata [1] was based on the inquiry training involving students to observe phenomena, formulate problems (C4) and hypotheses (C6). Students were also trained on how to determine the variables (C5) and develop experimental procedures (C6). When experimental data has been obtained, students were trained to analyze (C4) and conclude (C5) whether the results of the experiments matched the hypothesis they had compiled [1]. This worksheet was developed to train students' high-order thinking skill in surface chemistry course. This course has four chapters including viscosity, surface tension, adsorption, and colloid. High-order thinking, often referred to as critical thinking skills, is more than a simple recall of facts or information retrieval but rather a function of the interaction between cognitive strategies, meta-cognition, and nonstrategic knowledge during problem solving [2]. Many researchers and educators considered high-order thinking the same as the complexity of the questions raised or given to the learners [3]. The complexity might be one of the aspects of high-order thinking skills, but it was not the only aspect [3].

The science laboratory, if structured properly, has the potential to develop many important high-order learning skills such as asking questions, developing critical thinking, and developing metacognitive skills [4]. Similarly, the surface chemistry laboratory activity, when using inquiry as the basis of laboratory activities, will provide a more valuable student learning experience compared to the traditional laboratory activities. This more valuable learning experience will give students the ability to be creative in surface chemistry course. Creative thinking skill is one of four skills needed in the $21 \mathrm{st}$ century. Creative thinking can be defined as the entire set of cognitive activities used by individuals according to a specific object, problem and condition, or a type of effort toward a particular event and the problem based on the capacity of the individuals [5]. If the students have creative thinking skills, they will be able to solve the problem they face not only in lectures but also in daily life. There is evidence that suggests an impact of creative learning environments on learners' academic achievement; increased confidence and resilience; enhanced motivation and engagement; development of social, emotional and thinking skills; and improved school attendance [6].

Inquiry is one of student-centered approaches that uses constructivism and social development theories of learning and teaching emphasis [7]. Although Scott's study cannot make any claims about the role of inquiry laboratories on improved learning, their results indicate that the students are more likely to complete a course with inquiry-based laboratories [8]. Perhaps, the use of inquiry has the effect of making the experience more valuable for students, and it increases their perseverance in the course [8]

Inquiry learning stands the usual advice about expository (lecture-style) teaching on its head: instead of presenting wellorganized knowledge to students, the teacher (or sometimes fellow students) poses thoughtful questions intended to stimulate discussion and investigation by students [9]. Thinking, for the purposes of this inquiry, is defined accordingly as the operation which presents facts suggests other facts (or truths) in such a way as to induce belief in the latter upon the warrant of the former [10]. 
High-order thinking skills require continuous training so that students are able to integrate them into their daily thinking patterns. One of several ways to implement it, is by integrating high-order thinking skill in a certain course especially in laboratory activity.

\section{METHODS}

This research is a descriptive research that describes the students' high level thinking skill in terms of their pretest and posttest in laboratory activity using laboratory activity worksheet with inquiry as the basis. The research was conducted in Chemistry Department Universitas Negeri Surabaya (Unesa) on even semester 2016-2017 in Chemical Education class of 2014 by implementing the design of One Shoot Case pretest posttest design. The research instruments were Pretest and Posttest sheet. This sheet is a matter of description used to know the mastery of the purpose of practice. This sheet consisted of phenomena, variables, problem formulation, hypotheses, experimental steps/procedures, experimental data, analysis of experimental results, and conclusions.

The students individually answered the questions about high-level skills on the practical topics they would work on. After obtaining an inquiry-based surface chemistry worksheet, the students work in groups to complete experimental design on the topic. They consulted their design to the lecturer of surface chemistry course before doing laboratory activity. After conducting the laboratory activity, the students answered the posttest questions about high-level skills on the topics of the lab work they have done individually. The students were regarded finished in completing the study if they gained score of 76 and the classical completeness was $80 \%$. The differences in highorder thinking skills before and after using laboratory activity worksheet were then analyzed by calculating the difference in the posttest and pretest ( $\mathrm{N}$ Gain score), calculated by the formula (1)

$<g \geq \frac{\%<G>}{\%<G \max >}=\frac{(\%<S f>-\%<S i>)}{100 \%-\%<S i>}$

TABLE I. $N$ GAIN SCORE INTERPRETATION
\begin{tabular}{|l|l|}
\hline$\langle\mathrm{g}\rangle$ & Criteria \\
\hline$\langle\mathrm{g}\rangle\langle 0.3$ & Less \\
\hline 0.7$\rangle<\mathrm{g}\rangle \geq 0.3$ & Enough \\
\hline$\langle\mathrm{g}\rangle \geq 0.7$ & High \\
\hline
\end{tabular}

The laboratory activity was reported by the group of students. From this report, the data of the students' creativity was gained. The creativity was evaluated based on elaboration, flexibility, fluency, and originality [11]. The score used is: $1=$ low, 2 = enough, 3 = high

\section{RESULTS AND DISCUSSION}

A data collection was conducted for the study from May to June 2017 at the Chemistry Department of Unesa. The pretest had been carried out which was then followed by the application of Physics chemistry manual IV guidebook for chemical class education students 2014 who took Surface Chemistry course. After the practicum was done and collected, the students report the result of lab activity then did the posttest. The following sections discuss each stage.

\section{A. Pretest}

A total of 44 students were divided into 2 classes classified into 14 groups of experiments program Surface Chemistry course in the even semester of 2016-2017 academic year. Before the students carried out the practicum which was one of the requirements in programming the subjects of Surface Chemistry, the students had already performed the pretest in early May 2017. The data of the pretest scores obtained by the students were presented in Table 5.3. The students' pretest issues dealt with high-order thinking skill in C4 to C6 level. The question has been developed in Yonata's study [1].

\section{B. The Practicum Group works on a practicum guide}

The implementation of this manual was carried out in 4 weeks where every week the students in the groups practiced practicum once. This Surface Chemistry laboratory activity was guided by a laboratory activity worksheet developed by Yonata et al [1]. In the worksheet there were four titles/topics that had different format of the presentation sequence [1]. Table 1 presents the difference of sequence format on all four labels. From Table 1, it can be seen that the inquiry stages were trained differently in each title. In this free inquiry, the students were placed to work like a scientist.

TABLE II. SEQUENCE OF FORMAT OF SURFACE CHEMISTRY LABORATORY ACTIVITY WORKSHEET

\begin{tabular}{|c|c|c|c|c|c|c|c|c|c|}
\hline \multirow[t]{2}{*}{ Title/topic } & \multicolumn{9}{|c|}{ Sequence } \\
\hline & 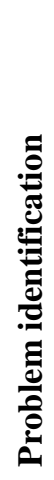 & 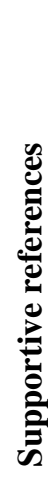 & 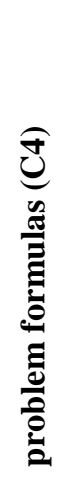 & 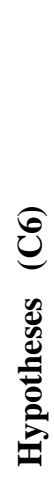 & 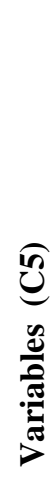 & 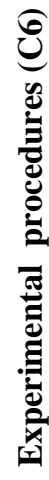 & 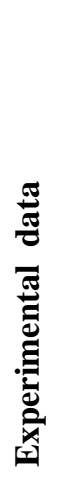 & 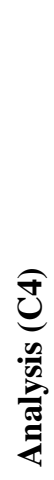 & 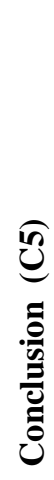 \\
\hline Viscosity & 1 & 2 & 3 & 4 & 5 & 6 & 7 & 8 & 9 \\
\hline $\begin{array}{l}\text { Surface } \\
\text { tension }\end{array}$ & - & 1 & 3 & 4 & 2 & 5 & 6 & 7 & 8 \\
\hline Colloid & - & 1 & 3 & 4 & 2 & 5 & 6 & 7 & 8 \\
\hline Adsorption & - & 1 & 3 & 4 & 2 & 5 & 6 & 7 & 8 \\
\hline
\end{tabular}

The stages for each title are listed in Table 1. The students completed the work by filling in the space provided in this manual with the basis of reference books and research journals. They were expected to have the ability to analyze important information in the completion of the worksheet. Technically each group must complete each stage listed in the Surface 
Chemistry laboratory activity worksheet which has been read by each group prior to the practicum.

In problem identification, students read the phenomena. These phenomena could rise student's interest to solve the problem. This technique was used as a start in the inquiry-based learning process called Orientation. Orientation was needed because the students did not only get an idea about the topic to be investigated but they were also introduced to the problem to be solved [12].

Before conducting the lab, the students (and their groups) planned the practicum and then discussed it with the lecturer. The practicum that the students did must follow the path listed in the Surface Chemistry worksheet. For one week, each group was allowed to discuss the group's thoughts to the lecturer of Surface Chemistry by showing their thoughts through the completed Surface Chemistry worksheet. Different lab headings guided the students in different ways as shown in Table 2. Each group could discuss with a lecturer in Surface Chemistry ranges one to two times before being approved to be carried out to the practicum. In detail, Table 2 shows the frequency of each group's discussion with the lecturer in Surface Chemistry course.

TABLE III. FREQUENCY OF EACH GROUP'S DISCUSSION WITH LECTURER

\begin{tabular}{|c|c|c|c|c|}
\hline \multirow{2}{*}{$\begin{array}{l}\text { Students } \\
\text { group }\end{array}$} & \multicolumn{4}{|c|}{ Frequency of discussion on Title/topic lab } \\
\cline { 2 - 5 } & Viscosity & $\begin{array}{c}\text { Surface } \\
\text { Tension }\end{array}$ & Colloid & Adsorption \\
\hline $\mathbf{1}$ & 1 & 2 & 2 & 1 \\
\hline $\mathbf{2}$ & 2 & 2 & 2 & 2 \\
\hline $\mathbf{3}$ & 2 & 2 & 2 & 2 \\
\hline $\mathbf{4}$ & 2 & 2 & 1 & 1 \\
\hline $\mathbf{5}$ & 2 & 2 & 2 & 1 \\
\hline $\mathbf{6}$ & 2 & 2 & 1 & 1 \\
\hline $\mathbf{7}$ & 2 & 1 & 2 & 2 \\
\hline $\mathbf{8}$ & 2 & 1 & 2 & 2 \\
\hline $\mathbf{9}$ & 2 & 2 & 1 & 1 \\
\hline $\mathbf{1 0}$ & 2 & 1 & 1 & 1 \\
\hline $\mathbf{1 1}$ & 2 & 1 & 2 & 2 \\
\hline $\mathbf{1 2}$ & 2 & 2 & 1 & 2 \\
\hline $\mathbf{1 3}$ & 2 & 2 & 2 & 1 \\
\hline $\mathbf{1 4}$ & 2 & 2 & 1 & 2 \\
\hline
\end{tabular}

It can be seen from Table 3 that each group conveyed and consulted the results of their thoughts in solving the problem as much as 1 time and 2 times per practicum title. It was the cause of the need of time for lecturers in guiding their students to be very long. Students in the group showed a problem-solving plan to get the entry and approval to proceed to the proof stage (practicum). Such result is in line with Daly study, that students showed agreement that receiving feedback from instructors was both frequent and influential [13].

If the group was considered to be ready and the procedure prepared by the students had paid attention to the tools and materials available in Physical Chemistry laboratory, then each group of students could implement the practice plan according to the schedule that had been set.
The data obtained by the students at the time of practicum should be discussed with the lecturer. This is done so that the objectives that set at the beginning before the lab could be evaluated first. The data already analyzed were also discussed before the preparation of the practicum report.

Afterwards, the students report was presented in the form of a practicum report. The practicum report should follow the format presented. It was done to maintain the consistency of the flow of students' thinking. At this stage, the students were asked to prepare reports such as stages in the inquiry model of learning and was expected to be able to use the discussions aimed at improving their understanding of the material delivered in the subject of Surface Chemistry. Inquiry learning stood for the usual advice about expository (lecture-style) teaching on its head: instead of presenting well-organized knowledge to students, the teacher (or sometimes the fellow students) posed thoughtful questions intended to stimulate discussion and investigation by the students [9].

\section{Student Creativity and Posttest}

At the end of the whole lab work (4 titles), the students carried out the posttest to know their final ability related highorder thinking skill. The posttests were conducted at the end of May 2017. The students answers in the posttest also showed the creativity based on the 4 criteria (elaboration, flexibility, fluency, and originality). The pretest, posttest, creativity (in average), and N-Gain results are presented in Table 3.

TABLE IV. PRETEST AND POSTTEST SCORES

\begin{tabular}{|c|c|c|c|c|c|c|c|}
\hline \multirow{2}{*}{$\begin{array}{c}\text { Student } \\
\text { No. }\end{array}$} & \multicolumn{2}{|c|}{ Pretest } & \multicolumn{2}{|c|}{ Posttest } & \multirow[b]{2}{*}{$\mathrm{C}$} & \multirow{2}{*}{$\begin{array}{c}\mathbf{N} \\
\text { Gain }\end{array}$} & \multirow[t]{2}{*}{ Category } \\
\hline & $\mathbf{S}$ & $\mathbf{M}$ & $\mathbf{S}$ & $\mathbf{M}$ & & & \\
\hline 1 & 75 & $\mathrm{NM}$ & 100 & $\mathrm{M}$ & 3 & 1 & High \\
\hline 2 & 79.2 & $\mathrm{M}$ & 100 & $\mathrm{M}$ & 3 & 1 & High \\
\hline 3 & 45.8 & NM & 95.8 & M & 3 & 0.9 & High \\
\hline 4 & 62.5 & $\mathrm{NM}$ & 95.8 & $\mathrm{M}$ & 3 & 0.9 & High \\
\hline 5 & 70.8 & NM & 100 & $\mathrm{M}$ & 3 & 1 & High \\
\hline 6 & 62.5 & $\mathrm{NM}$ & 100 & $\mathrm{M}$ & 3 & 1 & High \\
\hline 7 & 62.5 & NM & 100 & $\mathrm{M}$ & 3 & 1 & High \\
\hline 8 & 58.3 & NM & 100 & M & 3 & 1 & High \\
\hline 9 & 75 & NM & 87.5 & $\mathrm{M}$ & 2 & 0.5 & Enough \\
\hline 10 & 62.5 & NM & 95.8 & M & 3 & 0.9 & High \\
\hline 11 & 70.8 & $\mathrm{NM}$ & 95.8 & $\mathrm{M}$ & 3 & 0.9 & High \\
\hline 12 & 45.8 & NM & 100 & $\mathrm{M}$ & 3 & 1 & High \\
\hline 13 & 75 & NM & 100 & $\mathrm{M}$ & 3 & 1 & High \\
\hline 14 & 75 & NM & 95.8 & M & 3 & 0.8 & High \\
\hline 15 & 37.5 & $\mathrm{NM}$ & 100 & $\mathrm{M}$ & 3 & 1 & High \\
\hline 16 & 66.7 & $\mathrm{NM}$ & 91.7 & $\mathrm{M}$ & 3 & 0.8 & High \\
\hline 17 & 45.8 & NM & 91.7 & M & 3 & 0.8 & High \\
\hline 18 & 62.5 & NM & 100 & $\mathrm{M}$ & 3 & 1 & High \\
\hline 19 & 41.7 & NM & 100 & M & 3 & 1 & High \\
\hline 20 & 66.7 & NM & 100 & $\mathrm{M}$ & 3 & 1 & High \\
\hline 21 & 83.3 & $\mathrm{M}$ & 100 & M & 3 & 1 & High \\
\hline
\end{tabular}




\begin{tabular}{|c|c|c|c|c|c|c|c|}
\hline \multirow{2}{*}{\begin{tabular}{|c|} 
Student \\
No.
\end{tabular}} & \multicolumn{2}{|c|}{ Pretest } & \multicolumn{2}{|c|}{ Posttest } & \multirow[b]{2}{*}{$\mathbf{C}$} & \multirow{2}{*}{$\begin{array}{c}\mathbf{N} \\
\text { Gain }\end{array}$} & \multirow[t]{2}{*}{ Category } \\
\hline & $\mathbf{S}$ & $\mathbf{M}$ & $\mathbf{S}$ & M & & & \\
\hline 22 & 91.7 & $M$ & 100 & $\mathrm{M}$ & 3 & 1 & High \\
\hline 23 & 87.5 & $\mathrm{M}$ & 95.8 & $\mathrm{M}$ & 3 & 0.7 & High \\
\hline 24 & 66.7 & NM & 95.8 & $\mathrm{M}$ & 3 & 0.9 & High \\
\hline 25 & 91.7 & $\mathrm{M}$ & 100 & $\mathrm{M}$ & 3 & 1 & High \\
\hline 26 & 83.3 & $\mathrm{M}$ & 100 & $\mathrm{M}$ & 3 & 1 & High \\
\hline 27 & 83.3 & $\mathrm{M}$ & 83.3 & $\mathrm{M}$ & 2 & 0 & Low \\
\hline 28 & 79.2 & $\mathrm{M}$ & 95.8 & $\mathrm{M}$ & 3 & 0.8 & High \\
\hline 29 & 33.3 & NM & 100 & M & 3 & 1 & High \\
\hline 30 & 79.2 & $M$ & 100 & $\mathrm{M}$ & 3 & 1 & High \\
\hline 31 & 87.5 & $\mathrm{M}$ & 100 & $\mathrm{M}$ & 3 & 1 & High \\
\hline 32 & 79.2 & $\mathrm{M}$ & 100 & $\mathrm{M}$ & 3 & 1 & High \\
\hline 33 & 79.2 & $\mathrm{M}$ & 95.8 & $\mathrm{M}$ & 3 & 0.8 & High \\
\hline 34 & 75 & NM & 95.8 & $M$ & 3 & 0.8 & High \\
\hline 35 & 66.7 & NM & 100 & $\mathrm{M}$ & 3 & 1 & High \\
\hline 36 & 66.7 & NM & 100 & $\mathrm{M}$ & 3 & 1 & High \\
\hline 37 & 79.2 & $\mathrm{M}$ & 95.8 & $\mathrm{M}$ & 3 & 0.8 & High \\
\hline 38 & 79.2 & $\mathrm{M}$ & 100 & $\mathrm{M}$ & 3 & 1 & High \\
\hline 39 & 79.2 & $\mathrm{M}$ & 100 & $\mathrm{M}$ & 3 & 1 & High \\
\hline 40 & 91.7 & M & 100 & M & 3 & 1 & High \\
\hline 41 & 75 & NM & 91.7 & $\mathrm{M}$ & 3 & 0.7 & High \\
\hline 42 & 87.5 & $\mathrm{M}$ & 91.7 & $\mathrm{M}$ & 3 & 0.3 & Enough \\
\hline 43 & 91.7 & $\mathrm{M}$ & 100 & $\mathrm{M}$ & 3 & 1 & High \\
\hline 44 & 91.7 & $\mathrm{M}$ & 100 & $\mathrm{M}$ & 3 & 1 & High \\
\hline
\end{tabular}

$\mathrm{NM}=$ not mastery, $\mathrm{M}=$ mastery, $\mathrm{S}=$ Score, $\mathrm{M}=$ Mastery, $\mathrm{C}=$ Creativity

From the data presented in Table 3, it can be seen that the students were considered having high-order thinking skills shown by the students' ability in formulating the problem, formulate a hypothesis, determine the research variables, predict data and analysis, as well as formulating conclusions. From the results of the data analysis, it was found that $61 \%$ of the students had completed the target in pretest and $100 \%$ of the completed the target in the posttest.

The high-order thinking skill level analysis (C4) was tested to the student through completion of problem formulation and data analysis. The students' ability in pretest showed a range of score of 1 to 4 with an average of 3.27 for formulating problems and 0-4 with an average of 2.25 for the data analysis. From the posttest score, it was obtained that the score ranged from 3 to 4 with an average score of 3.98 for formulating the problem and 3.68 for the data analysis. The students' ability to analyze (C4) as shown by the difference of score achieved during pretest and posttest showed that the student's diligence could be analyzed by using laboratory activities worksheet.

Determining the experimental variables and concluding the experimental results was two of those practicum activities that could train high-order thinking skills in evaluation level or C5 in Bloom's revised taxonomy. These evaluating skills were actually owned by the students although it was not high. It was evidenced by the value of the pretest which got the score 1-4 and the average score of 2.82 for the determination of variables and $0-4$ and the average of 2.43 for the conclusion. The students' ability to evaluate was practiced at the practicum until the scores of 3-4 in posttest were obtained. The average score of 44 students to determine the experimental variable was 3.84 and to conclude the experimental results was 3.98.

The high-order thinking skills C6 level or creating, was obtained from the students' ability in preparing hypotheses and practices or experimental procedures. The pretest range of scores obtained by the students in preparing the hypothesis was ranged 1-4 with an average of 3.23 . To produce the experimental procedure, the students demonstrate a capability which was comparable to the hypothesis in the range of 1-4 with an average of 3.18. Through the practice in the lab, the results were obtained in the posttest in which it showed 3-4 scores for both C6 level abilities with an average score of 3.98 for the hypothesis and 3.96 for the experimental procedure.

Based on the data presented in Table 3, the creativity of the students was gained from the group report of laboratory activities. The students in the group discussed their plan of laboratory activities before conducting an experiment. If their plans were permitted by lecturer, they could continue to conduct the experiment. Table 2 shows some students tried to create their procedure to solve the problem given in the student's laboratory activity Worksheet. The activity could train the students' thinking skills especially their creativity. The training provided marginal improvements in creative problemsolving skills by reducing perceptual and functional fixations and mental blocks [14].

In relation to the fluency thinking, the students in group were asked to report their plan on determining research variables, problem formulation, and formulating hypotheses. The students' creative thinking skill was shown in their way to convey their ideas. One group idea differed from other groups ideas especially in determining research variables. For example, in viscosity topic, one group used sugar solution in different concentration to show the effect of concentration of solute in viscosity.

The flexibility was shown by the determination of variables, problem formulation, hypotheses formulation and experimental procedures, experimental data, and analysis. Those first three activities were not only for fluency thinking but also for the characteristics of flexible thinking. Flexibility was seen as the ability of adapting to changing conditions; and fluency was seen as a quick sequencing of ideas [15].

The elaboration was shown in data analysis. After students got experimental data, they analyzed their findings then elaborated it with their knowledge and the theories they read. The activity trained students thinking skills in integrated way. In the aforementioned activity, the students read several journals related to their topic.

The originality was shown in experimental procedures and conclusion. In this case, based on the formulation of the problem, the activity consisted of planning the investigation and drawing conclusions. When the students concluded their 
finding of the experiment, they should pay attention on the experimental data and the existing theories regarding to those four topics (viscosity, surface tension, adsorption, and colloid). The conclusion that had to be proved were the hypotheses of being correct or incorrect. For example, in viscosity, the hypotheses were as high as the concentration of sugar or as high the viscosity of sugar solution. If their experimental data showed that high concentration of sugar solution gave respond to the length of flow time, it meant that the hypotheses was accepted.

The aforementioned finding was in line with Daly's study explaining that student's perceptions of helpful pedagogy about the creative process dealing with the focus on practice-based, cooperative, and open-ended qualities [13].

\section{CONCLUSIONS AND SUGGESTION}

\section{A. Conclusion}

This research succeeds to train students' high-order thinking skill shown by the posttest done by the students in the assessment of high-order thinking skill. They were able to achieve the $100 \%$ completeness. Meanwhile, the creativity aspect was already shown by the students based on the posttest.

\section{B. suggestions}

It took a long time from the discussion of the practicum plan to the practicum implementation to be one of the factors involved in the application of the surface chemistry laboratory activity worksheet. For the future expectation, such way can be considered as an effective method in implementing laboratory activities.

\section{REFERENCES}

[1] G. Eason, B. Noble, and I.N. Sneddon, "On certain integrals of LipschitzHankel type involving products of Bessel functions," Phil. Trans. Roy. Soc. London, vol. A247, pp. 529-551, April 1955. (references)

[2] J. Clerk Maxwell, A Treatise on Electricity and Magnetism, 3rd ed., vol. 2. Oxford: Clarendon, 1892, pp.68-73.

[3] I.S. Jacobs and C.P. Bean, "Fine particles, thin films and exchange anisotropy," in Magnetism, vol. III, G.T. Rado and H. Suhl, Eds. New York: Academic, 1963, pp. 271-350.

[4] K. Elissa, "Title of paper if known," unpublished.

[5] R. Nicole, "Title of paper with only first word capitalized," J. Name Stand. Abbrev., in press.

[6] Y. Yorozu, M. Hirano, K. Oka, and Y. Tagawa, "Electron spectroscopy studies on magneto-optical media and plastic substrate interface," IEEE
Transl. J. Magn. Japan, vol. 2, pp. 740-741, August 1987 [Digests 9th Annual Conf. Magnetics Japan, p. 301, 1982].

[7] M. Young, The Technical Writer's Handbook. Mill Valley, CA: University Science, 1989.

[8] Y Bertha and N. Harun, "Laboratory Activity Worksheet to Train High Order Thinking Skill of Student on Surface Chemistry Lecture," IOP Conf. Series: Journal of Physics: Conf. Series, vol. 947, 2017, 012027.

[9] B. Ella, Research Brief: High Level Thinking and Questioning Strategies. 2010. Accessed on 11 October 2016. http://www.educationpartnerships.org/.

[10] Y, Abosalem, “Assessment Techniques and Students' Higher-Order Thinking Skills," International Journal of Secondary Education. vol. 4, no. 1, 2016, pp. 1-11. doi: 10.11648/j.ijsedu.20160401.11

[11] K. Dvora, H. Avi \& N. R. Mamlok, "Argumentation in the Chemistry Laboratory: Inquiry and Confirmatory Experiments," Springer: Research Science Education Journal, vol. 43, 2013 pp317-345.

[12] B, Bengi, "Creative and Critical Thinking Skills in Problem-based Learning Environments," Journal of Gifted Education and Creativity, vol. 2 no. 2, 2015 pp 71-80.

[13] D. Davies, D. Jindal-Snape, C. Collier, R. Digbya, P. Haya, A. Howea, "Creative learning environments in education-A systematic literature review," Thinking Skills and Creativity vol.8, 2013 pp.80-91.

[14] M. O. Valente, J. Fonseca and J. Conboy, "Inquiry science teaching in Portugal and some other countries as measured by PISA 2006," Procedia Social and Behavioral Sciences, vol.12, 2011 pp.255-262.

[15] P. Scott, and T. C. Pentecost, "From Verification to Guided Inquiry: What Happens When a Chemistry Laboratory Curriculum Changes?" National Science Teachers Association: Journal of College Science Teaching. vol. 42. no. 3. 2013 pp 82-88.

[16] K. Seifert and R. Sutton, Educational Psychology Zurich. Switzerland: The Global Text Project. 2011

[17] J. Dewey, How We Think. In -. "The Problem of Training Thought (page. 1), Boston: D.C. Heath \& Co, 1910

[18] R.R. Hake, "Interactive Engagement versus Traditional Methods: A Six Thousand Student Survey of Mechanics Test Data for Introductory Physics Courses," American Journal Physics. vol. 66, no. 1, 1998, pp 6474.

[19] M. Pedaste, M. Mäeots, L. A. Siiman, T. De Jong, S. A. Van Riesen, E.T. Kamp, C. C. Manoli, Z. C. Zacharia, E. Tsourlidaki, "Phases of inquirybased learning: Definitions and the inquiry cycle" Educational Research Review, vol.14, 2015, pp47-61

[20] S. R. Daly, E. A. Mosyjowski, S. L. Oprea, A. Huang-Saad, and C. M. Seifert. "College students' views of creative process instruction across disciplines." Thinking Skills and Creativity, vol.22, 2016, pp1-13

[21] S. M. Ritter, \& N. Mostert, "Enhancement of Creative Thinking Skills Using a Cognitive-Based Creativity Training", Journal of Cognitive Enhancement, vol 1 no.3, pp243-253.

[22] H. Türkmen and M. Sertkahya, "Creative Thinking Skills Analyzes Of Vocational High School Students" Journal of Educational and Instructional Studies in the World February, vol.5 Issue: 1 Article: 10, 2015 ISSN: 2146-7463 (74-84). 